\title{
Effects of Post-véraison Water Deficit on 'Pinot noir' Yield and Nutrient Status in Leaves, Clusters, and Musts
}

\author{
R. Paul Schreiner ${ }^{1}$ \\ USDA-ARS, Horticultural Crops Research Unit, 3420 NW Orchard Avenue, \\ Corvallis, OR 97330
}

Jungmin Lee

USDA-ARS, Horticultural Crops Research Unit Worksite, 29603 U of I Lane, Parma, ID 83660

Additional index words. drought, growth, Vitis vinifera, YAN, yield

\begin{abstract}
Pinot noir' grapevines were grown in a pot-in-pot system using a red-hill-soil where volumetric soil water content $\left(\theta_{v}\right)$ was carefully controlled. Four-year-old vines were supplied with one of two irrigation regimes (wet or dry) between véraison and fruit maturity and the experiment was repeated over 2 years. From véraison to harvest, vines in the wet treatment received irrigation whenever $\theta_{\mathrm{v}}$ approached $\approx 15 \%$ maintaining leaf water potential $\left(\Psi_{\text {leaf }}\right)$ above $-1.0 \mathrm{MPa}$. Vines in the dry treatment received irrigation when $\theta_{\mathrm{v}}$ approached $11 \%$ to $12 \%$ and experienced significant water stress $\left(\Psi_{\text {leaf }} \approx-1.4\right.$ MPa) before water was re-supplied. Vines were destructively harvested at véraison and at fruit maturity to determine biomass and nutrient content in the current season's above-ground tissues. Fruit yield, maturity indices, and must nutrient composition were measured at maturity. Irrigation did not influence vine growth in either year nor did it influence yield or fruit maturity indices. Irrigation also had no influence on leaf, whole cluster, or must mineral nutrient concentrations. Vine growth, yield, and nutrient status in leaves and musts varied by year. Vegetative growth was greater in 2007 than 2008, whereas yield and cluster weights were greater in 2008. Also in 2008, whole clusters obtained a greater proportion of dry matter and nutrients after véraison when differing irrigation treatments were imposed. Nonetheless, irrigation did not affect must chemical composition. These findings suggest that periodic post-véraison water deficits that are moderate to severe have little effect on berry nutrient and sugar accumulation in 'Pinot noir' cropped at typical levels for this variety.
\end{abstract}

Previous findings of mineral nutrient accumulation in whole 'Pinot noir' clusters from a non-irrigated vineyard suggested that post-véraison nutrient [particularly nitrogen $(\mathrm{N})$, phosphorus $(\mathrm{P})$, and potassium $(\mathrm{K})]$ import to berries could be limited by low soil water content (Schreiner et al., 2006). However, juice nutrients, including yeast assimilable nitrogen (YAN) concentration, were not determined in that study. Increasing water supply to grapevines, whether accomplished with varying irrigation levels or as a result of seasonal differences in rainfall, can increase must YAN levels (Nicolini et al., 2004; Wade et al., 2004). Seasonal variation in must YAN concentrations was weakly correlated with the amount of late summer rainfall over a 5 -year period in a western Oregon 'Pinot noir' vineyard (P.A. Skinkis, unpublished data).

\footnotetext{
Received for publication 20 May 2014. Accepted for publication 19 Aug. 2014

This project was funded by USDA-ARS CRIS projects \#5358-21000-048-00D and \#5358-21000-047-00D.

We thank Matthew Scott, Timothy Nam, John Carter, Scott Robbins, Suean Ott, and Christopher Rennaker for technical assistance.

${ }^{1}$ To whom reprint requests should be addressed; e-mail Paul.Schreiner@ars.usda.gov.
}

the impact of a post-véraison water deficit on vine growth, yield, and nutrient status in leaves and musts.

\section{Materials and Methods}

Grafted 'Pinot noir' grapevines (Dijon 115 clone on $3309 \mathrm{C}$ rootstock) were grown in 60 -L pot-in-pot microplots, as previously described (Schreiner et al., 2013), for 3 years before data collection. Sixty microplots were planted in 2004 and another 60 were planted in 2005 in two adjacent rows comprised of five blocks of 10 vines each. Half of the vines were randomly placed in either the wet or dry treatment, where different levels of water were supplied between véraison and harvest in the experimental year and in the previous year (see below). Data were collected from 4-year-old vines producing their first full crop; thus, vines measured in 2007 were planted in 2004, and vines measured in 2008 were planted in 2005. Vines were spaced at $1.0 \mathrm{~m} \times 3.2 \mathrm{~m}$, cane-pruned, and head-trained on a single Guyot system using vertical shoot positioning. The head height of vines was $0.6 \mathrm{~m}$ above ground and main shoots were trimmed $\approx 2$ weeks after fruit set at a height of $2.6 \mathrm{~m}$ above ground. Pots were filled with a 1:1 (vol:vol) mixture of coarse sand (Pre-Stress Sand Mix; Knife River Inc., Corvallis, OR) and Jory series soil (fine, mixed, active, mesic Xeric Haplohumult) collected from the Oregon State University, Woodhall Research Vineyard (Alpine, OR) Dolomite lime $\left(50 \% \mathrm{CaCO}_{3}, 40 \% \mathrm{MgCO}_{3}\right)$ was added to the mixed soil at a rate of $25 \mathrm{~g} \cdot \mathrm{kg}^{-1}$ dry soil to raise soil $\mathrm{pH}$ to $\approx 6.0$. Each microplot was fertilized at budbreak in each year with $50 \mathrm{~g}$ of $20 \mathrm{~N}-4.4 \mathrm{P}-16.6 \mathrm{~K}$ complete fertilizer with micronutrients (Peters Professional ${ }^{\circledR}$ water soluble fertilizer; Everris, Marysville, $\mathrm{OH}$ ). Fertilizer was broadcast over the pot surface and incorporated into the upper 2 to $3 \mathrm{~cm}$ of soil. This provided the $\mathrm{N}$ equivalent of $34 \mathrm{~kg} \cdot \mathrm{ha}^{-1}$.

Vines were drip-irrigated using four pressure-compensating emitters $\left(1.9 \mathrm{~L} \cdot \mathrm{h}^{-1}\right)$ per microplot attached to a ring of tubing to disperse water evenly throughout the pots. Irrigation inputs were managed based on $\theta_{v}$ and vine water status. The $\theta_{\mathrm{v}}$ was measured by time domain reflectometry (TDR) using $20 \mathrm{~cm}$ buriable, waveguides (6005TU-L20; Soil Moisture Equipment Corp., Santa Barbara, CA) that were installed vertically in two microplots per block at a depth of $10 \mathrm{~cm}$ below the soil surface halfway between the middle and side of the pots. The $\theta_{\mathrm{v}}$ was monitored daily from véraison to harvest, and irrigation was applied whenever $\theta_{\mathrm{v}}$ approached the target soil water content desired. TDR measurements were taken at $1600 \mathrm{HR}$ Pacific Standard Time. The $\theta_{\mathrm{v}}$ at field capacity and the permanent wilt point were previously determined in this soil mix at a bulk density of $1.35 \mathrm{~g} \cdot \mathrm{cm}^{-3}$ with a psychrometer (SC-10; Decagon Devices, Pullman, WA). The $\theta_{\mathrm{v}}$ at field capacity was $24 \%$, and $\theta_{\mathrm{v}}$ at the permanent wilt point (soil $\Psi=-1.5 \mathrm{MPa}$ ) was $9 \%$. In situ wilt tests were also conducted in 2006 in 
the dry vines planted in 2004 by withholding irrigation just before véraison and monitoring visual wilt symptoms, $\theta_{\mathrm{v}}$, and $\Psi_{\text {leaf }}$. Vines showed visual signs of leaf wilt and berries began to shrivel when $\theta_{\mathrm{v}}$ in individual microplots reached values between $11 \%$ and $12 \%$ and $\Psi_{\text {leaf }}$ values were $\approx-1.5 \mathrm{MPa}$ (data not shown). This test was conducted again $8 \mathrm{~d}$ later confirming that the wilt point in situ occurred when $\theta_{\mathrm{v}}$ was between $11 \%$ and $12 \%$ in individual microplots. Before véraison in each year all vines received the same level of irrigation; water was supplied during the night when $\theta_{\mathrm{v}}$ reached $\approx 15 \%$ at $1600 \mathrm{HR}$ Pacific Standard Time. Between véraison and fruit maturity in each year, vines in the wet treatment were irrigated using the same target for $\theta_{\mathrm{v}}$, whereas vines in the dry treatment were irrigated once $\theta_{\mathrm{v}}$ dropped below $12 \%$. In practice, this meant that the dry treatment was irrigated every $3 \mathrm{~d}$, and the wet treatment was irrigated every $2 \mathrm{~d}$ when the weather was warm and sunny shortly after véraison. Closer to harvest when the days were cooler and also on a few cloudy days or days with light rainfall, irrigation was withheld for longer periods in both wet and dry treatments. Water was applied at $2400 \mathrm{HR}$ Pacific Standard Time and daily irrigation quantities were based on supplying enough water to return microplots to field capacity using the average $\theta_{\mathrm{v}}$ value for a given treatment from the previous day. Weather data were obtained from the AgriMet weather station (U.S. Dept. of Interior, http://www.usbr.gov/ pn/agrimet/) located $8 \mathrm{~km}$ north of the experimental vineyard (Corvallis, OR).

Single leaf gas exchange was periodically measured between véraison and harvest with emphasis on obtaining data from a number of consecutive days shortly after imposing different irrigation regimes. Stomatal conductance $\left(g_{\mathrm{S}}\right)$ to water vapor was measured with a steady-state porometer (Model 1600; LI-COR Inc., Lincoln, NE) or with a portable infrared gas analyzer (IRGA) photosynthesis system (Model 6400; LI-COR Inc.) using both $\mathrm{CO}_{2}$ control (400 ppm with the mixer) and humidity control (set to ambient humidity within the canopy). Using humidity control with the 6400 most closely matches conditions of steady-state humidity used by the porometer. The two instruments were compared on 7 Sept. 2007 by measuring $g_{\mathrm{S}}$ on the same leaves (using either side of each leaf for each device) in the wet and dry treatments. Rates of $g_{\mathrm{S}}$ obtained on this day did not differ between the two instruments $(P>0.05)$, although $g_{\mathrm{S}}$ was reduced in the dry treatment (data not shown). Rates of $\mathrm{CO}_{2}$ assimilation (A) were also recorded when the IRGA was used. The porometer was used when the IRGA was unavailable, because this equipment was shared among different laboratories. For both types of measurements, only fully exposed leaves (photosynthetically active radiation greater than $1800 \mu \mathrm{mol} \cdot \mathrm{m}^{-2} \cdot \mathrm{s}^{-1}$ ) from the lower or middle canopy were measured. Measurements of gas exchange were made between 1400 and 1600 HR Pacific Standard Time when the west side of the canopy was fully exposed to sunlight. Two leaves per irrigation treatment per block on the west aspect of the canopy were measured on clear days.

Midday $\Psi_{\text {leaf }}$ was measured on a few occasions each year using a pressure chamber (Model 610; PMS Instrument Company, Albany, OR). These data were not collected as often as gas exchange data to reduce the number of leaves removed from vines, which may have influenced whole vine biomass and nutrient contents. Leaf water potential was determined from the same leaves used for gas exchange by placing the leaf in a plastic bag and cutting the petiole with a razor blade immediately after taking gas exchange data.

Ten vines were destructively harvested at véraison and again at fruit maturity each year, five from the wet and five from the dry treatments representing each block. All of the leaves (without petiole), shoots, and clusters from each vine were washed with distilled water and blotted dry on cotton towels. Fresh weight for each plant part was recorded, and subsamples were dried to constant mass at $65^{\circ} \mathrm{C}$ as in Schreiner et al. (2006). Nitrogen concentration in each dried plant part was determined through combustion analysis (LECO Corp., St. Joseph, MI), and $\mathrm{P}, \mathrm{K}$, sulfur $(\mathrm{S})$, calcium $(\mathrm{Ca})$, magnesium $(\mathrm{Mg})$, manganese $(\mathrm{Mn})$, copper $(\mathrm{Cu})$, boron $(\mathrm{B})$, zinc $(\mathrm{Zn})$, and iron $(\mathrm{Fe})$ concentrations were measured by inductively coupled plasma-optical emission spectrometry (Optima 3000DV; PerkinElmer Inc., Wellesley, MA) after microwave digestion in $\mathrm{HNO}_{3}$ (Jones and Case, 1990). Certified tissue standard (apple leaves; National Institute of Standards and Technology, Gaithersburg, MD) was included in all nutrient assays. Total nutrient contents of whole clusters were derived from concentration and total dry biomass as described previously (Schreiner et al., 2006). The proportion of the final dry matter and total nutrient content $(\mathrm{N}, \mathrm{P}, \mathrm{K}, \mathrm{Ca}$, and $\mathrm{Mg}$ ) of whole clusters that had accrued between véraison and harvest was calculated by subtracting the mean quantity for each variable obtained at véraison from each harvest replicate and dividing the difference by the harvest value, expressed as percent.

The year before vines were to be used for this study (when vines were 3 years old) and in the experimental year each vine was pruned to eight buds plus one renewal spur and later thinned to six shoots and a renewal spur after threat of frost had passed. A small crop averaging 0.5 clusters per shoot was retained during the third growing season. The wet and dry treatment vines were differentially irrigated in Year 3 between véraison and harvest as well as the experimental year. Vines were managed the same in Year 4 (experimental year) as in Year 3, except that two fruit clusters were retained on each fruiting shoot in the experimental year.

Fruit parameters were determined from five vines in each irrigation treatment per year at harvest. Fruit yield, the number of clusters per vine, and average cluster weights were recorded for each vine. Berries were counted and weighed from a subsample of five randomly selected clusters from each vine. These berries were crushed using a small hand-crank press and total soluble solids, $\mathrm{pH}$, titratable acidity, and mineral concentrations of the must were determined as in Schreiner et al. (2013). Must samples were frozen and stored at $-80{ }^{\circ} \mathrm{C}$ for later determination free amino acid (FAA) profiles by high-performance liquid chromatography, ammonia by enzymatic assay, and recalculated as YAN, as previously described (Lee and Schreiner, 2010). The remaining clusters were used as the subsample that was dried for whole cluster mineral nutrient analysis.

Daily measurements of $\theta_{\mathrm{v}}, g_{\mathrm{S}}$, and $\Psi_{\text {leaf }}$ were subjected to analysis of variance (ANOVA) using irrigation treatment as the sole factor. Other variables were initially analyzed by ANOVA using year and irrigation treatment as factors. Irrigation treatment and the interaction between year and irrigation did not significantly alter any measured variable, so only year was included in the final ANOVA. Variance and normality assumptions for all measured variables were tested before ANOVA and no variables required transformation. All statistics were conducted using Statistica software (Statsoft, Tulsa, OK) and effects were considered significant at $95 \%$ confidence $(P \leq 0.05)$. Means were compared using Tukey's post hoc test at $95 \%$ confidence.

\section{Results}

Spring was cooler in 2008 and vine development was substantially delayed in that year compared with 2007 (Table 1). Budbreak and bloom occurred $\approx 2$ weeks later in 2008 than in 2007, but véraison and harvest were only delayed by $6 \mathrm{~d}$ and $5 \mathrm{~d}$ in 2008 vs. 2007. Solar radiation was greater within each growth period in 2007 than in 2008, whereas overall heat accumulation within each phenological period was similar between years. Slightly more irrigation water was applied during the veraison to harvest period in 2008 than in 2007 because of greater rainfall during that period in 2007. Overall, similar amounts of irrigation were applied in both years with the dry treatment receiving $23 \%$ less irrigation than the wet treatment from véraison to harvest. Summed over the entire growing season, vines in the dry treatment received $7 \%$ to $8 \%$ less irrigation than the wet treatment.

Soil water content did not differ between wet and dry treatments before the onset of different irrigation regimes at véraison in each year (data not shown). After véraison, $\theta_{\mathrm{v}}$ in wet microplots varied between $14 \%$ and $25 \%$ generally cycling between high and low values on a 2-d period when the weather was warm and sunny (Fig. 1). The dry microplots varied between $11 \%$ and $24 \% \theta_{v}$, usually reaching the low target value every third day, before being re-irrigated. As time progressed in each year, the irrigation cycles for both treatments became longer as vines used less water. Vines in the dry treatment experienced 


\begin{tabular}{|c|c|c|c|c|c|c|}
\hline \multirow[b]{2}{*}{ Yr/growth stage } & \multirow[b]{2}{*}{ GDD greater than $10^{\circ} \mathrm{C}^{\mathrm{z}}$} & \multirow[b]{2}{*}{ Solar radiation $\left(\mathrm{MJ} \cdot \mathrm{m}^{-2}\right)$} & \multirow[b]{2}{*}{$\mathrm{ET}_{\mathrm{ref}}(\mathrm{mm})^{\mathrm{y}}$} & \multirow[b]{2}{*}{ Rainfall (mm) } & \multicolumn{2}{|c|}{ Irrigation applied $(\mathrm{mm})^{x}$} \\
\hline & & & & & Wet & Dry \\
\hline Budbreak to bloom 15 Apr. to 18 June & 292 & 1,421 & 289 & 74 & 27 & 27 \\
\hline Bloom to véraison 18 June to $20 \mathrm{Aug}$. & 569 & 1,536 & 414 & 37 & 128 & 128 \\
\hline Season total 15 Apr. to 9 Oct. & 1,197 & 3,800 & 930 & 203 & 225 & 209 \\
\hline \multicolumn{7}{|l|}{2008} \\
\hline Véraison to harvest 26 Aug. to 14 Oct. & 319 & 799 & 192 & 46 & 77 & 59 \\
\hline Season total 3 May to 14 Oct. & 1,176 & 3,420 & 853 & 108 & 228 & 210 \\
\hline
\end{tabular}

${ }^{\mathrm{z}}$ Growing degree-days (GDD) calculated for each day using [(minimum temperature + maximum temperature)/2] $-10{ }^{\circ} \mathrm{C}$, with the minimum temperature. set to $10{ }^{\circ} \mathrm{C}$ whenever lower than this value.

${ }^{y}$ Reference evapotranspiration (ET) calculated using the 1982 Kimberly-Penman equation using an exponentially based wind function coefficient (Wright et al., 2000).

${ }^{x}$ Irrigation inputs converted to millimeters by dividing the volume of water applied by the surface area of the pot.

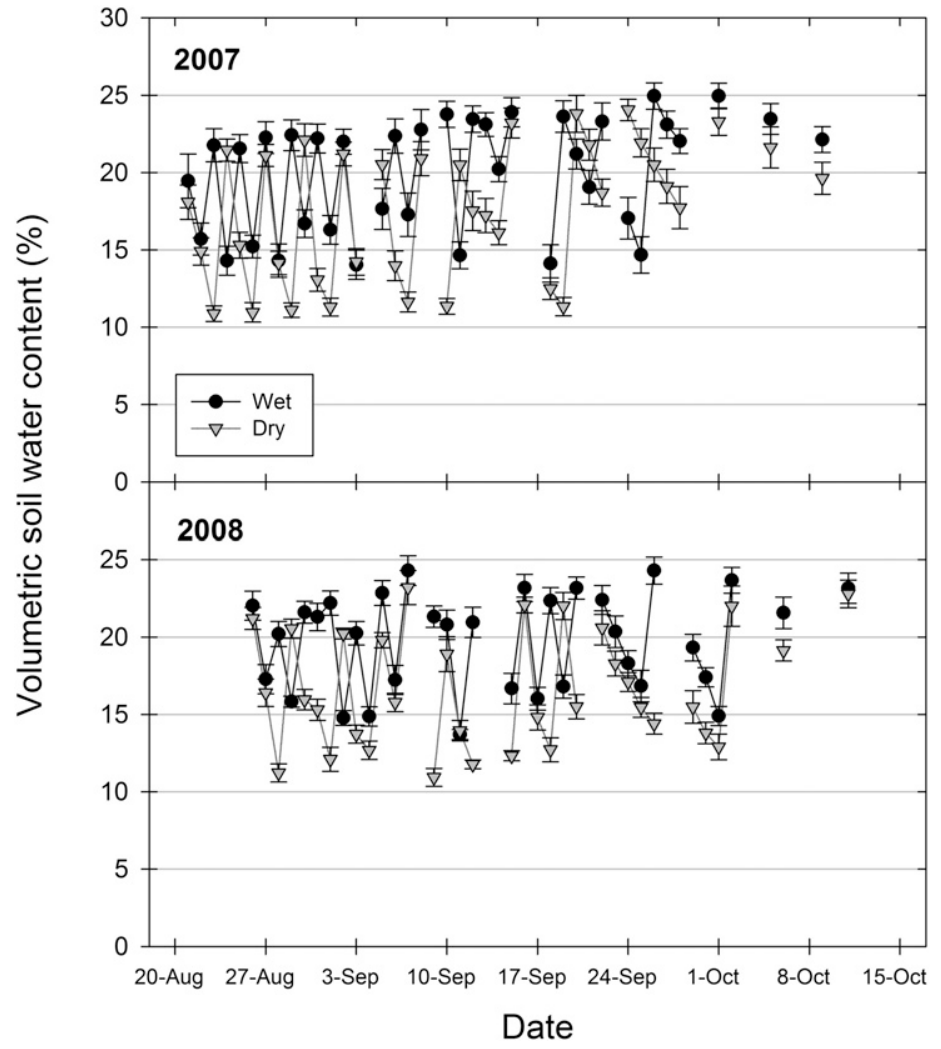

Fig. 1. Effect of irrigation treatment on percent volumetric soil water content in 4-year-old 'Pinot noir' grapevines grown in microplots between véraison and harvest over 2 years. Data are means (SE) from five replicates.

greater water limitation than vines in the wet treatment. For example, the lowest $\theta_{\mathrm{v}}$ that occurred in the wet microplots was $14.0 \%$ in 2007 and $13.7 \%$ in 2008 , whereas lowest values attained in dry microplots were $10.9 \%$ in both years. The extent of water limitation in the dry treatment was slightly more severe in 2007 than in 2008 (Fig. 1). For example, the number of measured days between véraison and harvest that dry microplots had $\theta_{\mathrm{v}}$ values below $13 \%$ was the same in both years $(8 \mathrm{~d})$, but $\theta_{\mathrm{v}}$ was below $12 \%$ on $7 \mathrm{~d}$ in 2007 , whereas only $4 \mathrm{~d}$ were lower than $12 \%$ in 2008 .

Stomatal conductance to water vapor was significantly lower in the dry vines on numerous days throughout the ripening period in both years (Table 2). The largest differences between wet and dry vines occurred on those days where dry microplots had not been irrigated for $2 \mathrm{~d}$ compared with 0 or $1 \mathrm{~d}$ without irrigation in wet microplots (23 Aug., 29 Aug., and 7 Sept. 2007; 28 Aug., 4 Sept., 9 Sept. 2008). Vines in the wet treatment typically had $g_{\mathrm{S}}$ values above $200 \mathrm{mmol} \cdot \mathrm{m}^{-2} \cdot \mathrm{s}^{-1}$ (highest value $402 \mathrm{mmol} \cdot \mathrm{m}^{-2} \cdot \mathrm{s}^{-1}$ ), except for a few days late in 2007 when air temperatures were cooler and on 11 Sept. 2008 also when $\theta_{\mathrm{v}}$ had reached the lowest level recorded that year in the wet treatment. Dry vines often had $g_{S}$ values between 30 and $60 \mathrm{mmol} \cdot \mathrm{m}^{-2} \cdot \mathrm{s}^{-1}$ on the last day before re-watering when $\theta_{\mathrm{v}}$ ranged from $10.9 \%$ to $11.2 \%$. The level of drought stress in the dry vines on the last day before re-wetting was moderate to severe (Flexas et al., 2002; Medrano et al., 2002) depending on the particular degree of water limitation $\left(\theta_{\mathrm{v}}\right)$ and weather on a given day. Assimilation of $\mathrm{CO}_{2}$ in single leaves was significantly lower in dry vines vs. wet vines on 7 Sept., 24 Sept., 25 Sept. 2007 and on 4 Sept. 2008, although $g_{\mathrm{S}}$ was only lower on 2 of those days, indicating that photosynthesis was more sensitive to stress-induced stomatal closure than water vapor loss (Table 2).

There were also 4 of the 16 measured days when $g_{\mathrm{S}}$ was significantly lower in dry vines than in wet vines although $\theta_{\mathrm{v}}$ did not differ. The wet and dry microplots were both irrigated at the same time before gas exchange measurements on 3 of these $4 \mathrm{~d}$, showing that once they had been stressed, the dry vines did not recover to similar rates of $g_{\mathrm{S}}$ as wet vines at a given $\theta_{\mathrm{v}}$. Leaf water potential was lower in dry vines as compared with wet vines on $4 \mathrm{~d}$ out of $8 \mathrm{~d}$ that it was assessed over both years (Table 2 ). On each day that $\Psi_{\text {leaf }}$ was lower in the dry vines, $\theta_{\mathrm{v}}$ was lower also corresponding with the end of the dry-down cycle in the dry microplots. Leaf water potential varied between $-1.37 \mathrm{MPa}$ and $-1.48 \mathrm{MPa}$ on the most stressful days in the dry vines, whereas it was above $-1.00 \mathrm{MPa}$ in the wet vines.

Some leaves on the dry vines developed a light red color in both years $\approx 2$ weeks after the lower rate of irrigation was initiated, indicating an accumulation of anthocyanins (Steyn et al., 2002). These visual symptoms occurred on older and mid-canopy leaves. Within single leaves the red color typically occurred in patches in the leaf interior, usually affecting zones of cells delineated along minor veins. The red symptoms were not confined to the leaf margin that typically occurs in response to $\mathrm{P}$ deficiency (Cook et al., 1983; Skinkis and Schreiner, 2011). No red leaves were observed on vines in the wet treatment. In addition, many leaves of dry vines had a less reflective green appearance under natural sunlight as compared with wet vines, which appeared more bright green. 
Table 2. Effect of irrigation on mean soil water content $\left(\theta_{\mathrm{v}}\right)$, stomatal conductance $\left(g_{\mathrm{S}}\right)$, assimilation $(\mathrm{A})$, and midday leaf water potential $\left(\Psi_{\text {leaf }}\right)$ in 4-year-old 'Pinot noir' grapevines grown in microplots in 2007 and 2008. ${ }^{z}$

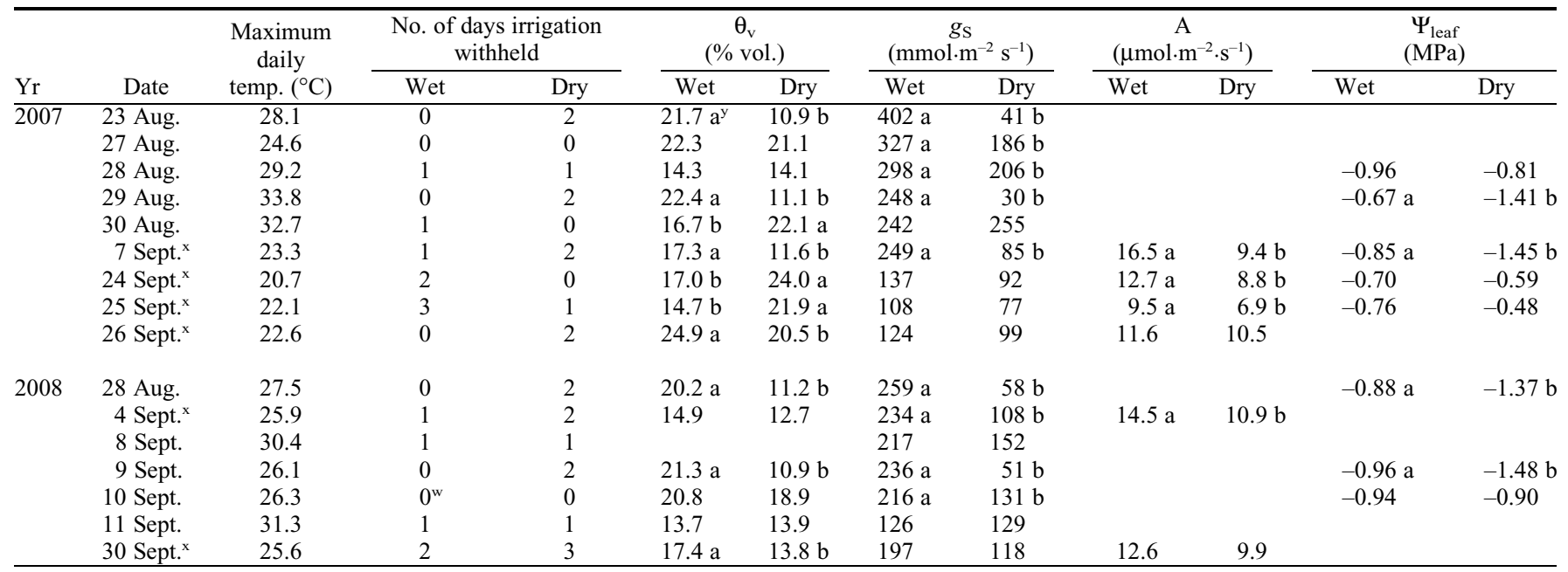

${ }^{\mathrm{z}}$ Data are mean values $(\mathrm{n}=10)$.

${ }^{\mathrm{y}}$ Means for each variable followed by a different letter within a row differ significantly based on Tukey's honestly significant difference test at $95 \%$ confidence. ${ }^{x}$ Measured with IRGA (LI-COR 6400 photosynthesis system); all other dates by steady-state porometer (LI-COR 1600).

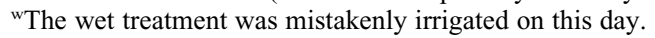

Table 3. Impact of year on vine growth, yield components, and nutrient status in leaves, clusters, and must from 4-year-old 'Pinot noir' grapevines grown in microplots. ${ }^{2}$

\begin{tabular}{|c|c|c|}
\hline \multirow[b]{2}{*}{ Variable } & \multicolumn{2}{|c|}{ Yr } \\
\hline & 2007 & 2008 \\
\hline Leaf dry weight (g/vine) & 174 & 163 \\
\hline Shoot dry weight ( $\mathrm{g} / \mathrm{vine})$ & $265 \mathrm{a}^{\mathrm{y}}$ & $198 \mathrm{~b}$ \\
\hline Shoot fresh weight at dormancy ( $\mathrm{g} / \mathrm{vine}$ ) & $412 \mathrm{a}$ & $327 \mathrm{~b}$ \\
\hline Fruit yield (kg/vine) & $0.80 \mathrm{~b}$ & $1.24 \mathrm{a}$ \\
\hline Cluster fresh weight $(\mathrm{g})$ & $69 \mathrm{~b}$ & $99 \mathrm{a}$ \\
\hline Berry fresh weight $(\mathrm{g})$ & 1.10 & 1.19 \\
\hline Seed fresh weight (mg/berry) & $55 \mathrm{~b}$ & $80 \mathrm{a}$ \\
\hline Leaf blade $\mathrm{N}\left(\mathrm{g} \cdot \mathrm{kg}^{-1} \mathrm{DW}\right)$ & 10.9 & 12.3 \\
\hline Leaf blade $\mathrm{P}\left(\mathrm{g} \cdot \mathrm{kg}^{-1} \mathrm{DW}\right)$ & 0.9 & 1.1 \\
\hline Leaf blade $\mathrm{K}\left(\mathrm{g} \cdot \mathrm{kg}^{-1} \mathrm{DW}\right)$ & $11.0 \mathrm{a}$ & $8.9 \mathrm{~b}$ \\
\hline Cluster N (g. $\left.\mathrm{kg}^{-1} \mathrm{DW}\right)$ & $8.0 \mathrm{a}$ & $6.5 \mathrm{~b}$ \\
\hline Cluster P $\left(\mathrm{g} \cdot \mathrm{kg}^{-1} \mathrm{DW}\right)$ & 1.4 & 1.5 \\
\hline Cluster $\mathrm{K}\left(\mathrm{g} \cdot \mathrm{kg}^{-1} \mathrm{DW}\right)$ & $14.0 \mathrm{a}$ & $12.8 \mathrm{~b}$ \\
\hline Must soluble solids ( ${ }^{\circ}$ Brix) & $20.3 \mathrm{~b}$ & $22.1 \mathrm{a}$ \\
\hline Must titratable acidity $\left(\mathrm{g} \cdot \mathrm{L}^{-1}\right)$ & $5.63 \mathrm{~b}$ & $7.28 \mathrm{a}$ \\
\hline Must $\mathrm{pH}$ & 3.32 & 3.29 \\
\hline Must YAN-N $\left(\mathrm{mg} \cdot \mathrm{L}^{-1}\right)$ & 373 & 328 \\
\hline Must ammonia-N $\left(\mathrm{mg} \cdot \mathrm{L}^{-1}\right)$ & 48 & 49 \\
\hline Must arginine- $\mathrm{N}\left(\mathrm{mg} \cdot \mathrm{L}^{-1}\right)$ & $223 \mathrm{a}$ & $174 \mathrm{~b}$ \\
\hline Must $\mathrm{P}\left(\mathrm{mg} \cdot \mathrm{L}^{-1}\right)$ & $225 \mathrm{a}$ & $180 \mathrm{~b}$ \\
\hline Must $\mathrm{K}\left(\mathrm{mg} \cdot \mathrm{L}^{-1}\right)$ & 1,784 & 1,709 \\
\hline
\end{tabular}

${ }^{\mathrm{z}}$ All measurements were conducted on samples at harvest, except shoot fresh weight at dormancy. Data are means $(\mathrm{n}=10)$.

${ }^{y}$ Means followed by a different letter in each row are significantly different based on Tukey's honestly significant difference test at $95 \%$ confidence.

${ }^{x}$ Yeast assimilable nitrogen (YAN) concentration was calculated by summing $\mathrm{NH}_{3}$ determined by enzymatic assay and individual primary free amino acids by high-performance liquid chromatography (Lee and Schreiner, 2010).

$\mathrm{N}=$ nitrogen; $\mathrm{DW}=$ dry weight $\mathrm{P}=$ phosphorus; $\mathrm{K}=$ potassuim.

The development of subtle, but clear, visual differences between the leaves in the wet and dry vines attest to the significant degree of drought stress imposed on dry vines.

The effect of irrigation treatment on vegetative growth, vine nutrient status, yield parameters, or must nutrient status was not apparent in young 'Pinot noir' grapevines. The interaction between year and irrigation treatment was also not significant $(P>0.05)$ for any measured variable. Only year altered growth, yield, and nutrient status of leaves, clusters, and musts (Table 3). Vines were more vegetative in 2007 than in 2008, producing greater dry biomass of shoots at harvest and fresh weight at dormant pruning, although leaf dry mass did not differ between years. Yield was greater in 2008 as a result of larger clusters, but berry weight did not differ between years. Seed weight per berry was also greater in 2008. Leaf $\mathrm{N}$ and $\mathrm{P}$ concentrations did not differ by year, but leaf $\mathrm{K}$ status was greater in 2007. Cluster $\mathrm{N}$ and $\mathrm{K}$ concentrations were greater in 2007, whereas cluster P did not vary by year. Both must soluble solids and titratable acidity were higher in 2008, but pH was unaffected by year. Finally, must YAN, ammonia-N, and K were similar between years, whereas must arginine and must $\mathrm{P}$ were at higher concentrations in 2007.

Other leaf, cluster, and must nutrients (including $\mathrm{Ca}, \mathrm{Mg}, \mathrm{S}, \mathrm{Fe}, \mathrm{Mn}, \mathrm{B}, \mathrm{Cu}$, and $\mathrm{Zn})$ were similarly not altered $(P>0.05)$ by irrigation or by the interaction between irrigation and year (data not shown). The concentrations of individual FAAs and the relative proportions of FAA-N contributed by each FAA in musts were not altered $(P>$ 0.05 ) by irrigation treatment nor by the interaction between year and irrigation treatment. However, eight amino acids (in addition to arginine) were altered by year with aspartic acid, glutamic acid, asparagine, and hydroxyproline at higher concentrations in 2007 must and serine, glycine, $\gamma$-amino butyric acid, and proline at higher concentrations in 2008. Arginine alone provided enough $\mathrm{N}$ in each year to meet minimum YAN requirements for successful fermentations, assuming $140 \mathrm{mg} \mathrm{N} / \mathrm{L}$ is required (Bely et al., 1990).

The large seasonal difference in vegetative vs. reproductive growth of 'Pinot noir' that occurred prompted an examination of whether the different irrigation levels altered the accumulation of biomass or nutrients in fruit clusters. Indeed, irrigation did not alter $(P>0.05)$ the proportion of macronutrients that were imported into whole clusters between véraison and harvest in either year, although the relative increase in dry mass during this period was far greater in 2008 than in 2007 (Table 4). In 2008, when vines produced a larger crop, a greater proportion of $\mathrm{P}, \mathrm{K}$, and $\mathrm{Mg}$ content was allocated to whole clusters during the ripening period than in 2007 . In $2007,80 \%$ to $90 \%$ of the final dry matter and macronutrient $(\mathrm{N}, \mathrm{P}, \mathrm{K}$, 
Table 4. Impact of year on the proportion of final dry matter and macronutrient contents gained by whole clusters between the time period of véraison to harvest in 4-year-old 'Pinot noir' grapevines grown in microplots. $^{\mathrm{z}}$

\begin{tabular}{llr}
\hline & \multicolumn{2}{c}{ Yr } \\
\cline { 2 - 3 } Percent of total accumulation from véraison-harvest & 2007 & 2008 \\
\hline Cluster dry matter & $21 \mathrm{~b}^{\mathrm{y}}$ & $44 \mathrm{a}$ \\
Cluster N & 18 & 23 \\
Cluster P & $12 \mathrm{~b}$ & $35 \mathrm{a}$ \\
Cluster K & $21 \mathrm{~b}$ & $41 \mathrm{a}$ \\
Cluster Ca & 6 & 14 \\
Cluster Mg & $9 \mathrm{~b}$ & $31 \mathrm{a}$ \\
\hline
\end{tabular}

${ }^{\mathrm{z}}$ Data are means $(\mathrm{n}=10)$.

${ }^{y}$ Means followed by a different letter in each row are significantly different based on Tukey's honestly significant difference test at $95 \%$ confidence.

$\mathrm{N}=$ nitrogen; $\mathrm{P}=$ phosphorus; $\mathrm{K}=$ potassium; $\mathrm{Ca}=$ calcium; $\mathrm{Mg}=$ magnesium.

$\mathrm{Ca}$, and $\mathrm{Mg}$ ) contents were already allocated to clusters by véraison, whereas in 2008 , only $56 \%$ of final dry matter and $59 \%$ of the total $\mathrm{K}$ content were imported to clusters by véraison.

\section{Discussion}

Results from this study indicate that periodic, post-véraison water stress in 'Pinot noir' grapevines carrying a relatively low crop load has no influence on the accumulation of sugars or mineral nutrients in berries. Typical yields for 'Pinot noir' in the region range from 4000 to $6500 \mathrm{~kg} \cdot \mathrm{ha}^{-1}$ (Schreiner et al., 2006). The vines here yielded 3140 $\mathrm{kg} \cdot \mathrm{ha}^{-1}$ in 2007 and $4500 \mathrm{~kg} \cdot \mathrm{ha}^{-1}$ in 2008. Thus, the impact of year on vine nutrient status and must composition that did occur was largely driven by this difference in crop load. The greater crop yield carried to maturity in 2008 led to reduced shoot biomass at harvest and at dormancy. A greater proportion of dry matter and nutrients was apportioned to clusters after véraison in 2008 as well. Thus, the 2008 season provided a robust test of whether post-véraison water deficits alter the accumulation of nutrients and sugars in berries. Because differing irrigation at this time did not affect whole cluster or must composition, our data suggest that there will be little negative impact of late-season water stress on must quality in 'Pinot noir' vineyards in this region. These findings support conclusions drawn from a greenhouse study where 'Pinot noir' was found to be less sensitive to water stress than 'Chardonnay' and was thus recommended as a better choice on drier sites in cool climate regions (Reynolds and Naylor, 1994).

Although numerous studies have found that sugars in berries are reduced by water deficits and that $\mathrm{K}$ in berries is closely tied to the amount of irrigation applied (Freeman and Kliewer, 1983; Hepner and Bravdo, 1985; Klein et al., 2000); when water stress was applied after véraison, the impact on berry minerals such as $\mathrm{K}$ has been less consistently reduced than sugars (Esteban et al., 1999; Matthews and Anderson, 1988; Naor et al., 1993). Sugars are not always altered by post-véraison water deficits (Tarara et al., 2011) and variable effects on must YAN resulting from late-season water stress are also known (Bell and Henschke, 2005; Wade et al., 2004). Such variable responses to late-season water deficits in the accumulation of sugars and mineral nutrients are partly explained by differences in crop load across studies (Freeman and Kliewer, 1983; Naor et al., 1993). Indeed, sugars were reduced more strongly in 'Sauvignon blanc' exposed to late-season water stress in 2 years out of 4 when vines carried a much larger crop (Naor et al., 1993). Because 'Pinot noir' typically is cropped for lower yield than many other varieties, it is unlikely that YAN, other minerals, or sugars important for quality would be altered by periodic late-season water deficits. Based on our results with microplots, new 'Pinot noir' vineyards that are planted on de-vigorating rootstocks and managed with drip irrigation should be tolerant of short periods of fairly severe drought stress with little impact on fruit quality.

The somewhat severe drought stress experienced by the dry vines here ( $g_{\mathrm{S}}$ values between 30 to $60 \mathrm{mmol} \cdot \mathrm{m}^{-2} \cdot \mathrm{s}^{-1}$ ) was evident also based on the visual symptoms present on leaves. Furthermore, $g_{\mathrm{S}}$ did not always recover to a similar level as in the wet treatment on a number of occasions after dry vines were re-irrigated after water stress. Stomatal conductance of grapevines exposed to moderate water stress ( $g_{\mathrm{S}}$ values between 50 and 150 $\mathrm{mmol} \cdot \mathrm{m}^{-2} \cdot \mathrm{s}^{-1}$ ) typically recovers to that of non-stressed vines the day after re-irrigating vines, but recovery may take a few days after more severe stress ( $g_{\mathrm{S}}$ values below 50 $\mathrm{mmol} \cdot \mathrm{m}^{-2} \cdot \mathrm{s}^{-1}$ ) (Flexas et al., 2002; Medrano et al., 2002). Because data from 28 Aug. 2007 and 10 Sept. 2008 showed that the dry vines had fully recovered leaf water status $\left(\Psi_{\text {leaf }}\right)$ yet $g_{\mathrm{S}}$ had not fully recovered to the level observed in wet vines, leaf-derived abscisic acid may have remained high to reduce $g_{\mathrm{S}}$ to repair embolisms (Lovisolo et al., 2008). This seems likely because water supply to roots exposed to the same $\theta_{\mathrm{v}}$ would have been similar to the wet treatment, and thus root-delivered abscisic acid would likely have been similar also. The slow recovery of $g_{S}$ in the dry vines also limited carbon fixation on some days when $\theta_{\mathrm{v}}$ no longer differed, although these reductions in gas exchange at the leaf level did not reduce sugar accumulation in berries. Vines in the dry treatment used $23 \%$ less water than vines in wet treatment during the post-véraison period, suggesting greater water use efficiency with no negative impact on fruit ripening. Among cultivars of grapevines, 'Pinot noir' has been reported to be both efficient and inefficient in whole plant water use (Gibberd et al., 2001; Tomás et al., 2012).

The primary purpose of this study was to ascertain whether post-véraison water deficits reduced mineral nutrient accumulation in fruit. This did not occur in either year. However, must and whole cluster N, P, and $\mathrm{K}$ concentrations found here at harvest were generally high. Cluster $\mathrm{N}$ concentrations at harvest from a previous non-irrigated field trial in self-rooted 'Pinot noir' (Schreiner et al., 2006) were slightly lower ranging from 6.5 to $6.7 \mathrm{~g} \cdot \mathrm{kg}^{-1}$ dry weight compared with the range of 6.5 to $8.0 \mathrm{~g} \cdot \mathrm{kg}^{-1}$ dry weight observed in this study. Cluster P concentrations from the same previous field trial ranged from 0.8 to $1.1 \mathrm{~g} \cdot \mathrm{kg}^{-1}$ dry weight, whereas in this study, it was consistently higher at 1.4 to $1.5 \mathrm{~g} \cdot \mathrm{kg}^{-1}$ dry weight; and cluster $\mathrm{K}$ was also higher in this study (13 to $14 \mathrm{~g} \cdot \mathrm{kg}^{-1}$ dry weight) as compared with the previous trial (10 to $12 \mathrm{~g} \cdot \mathrm{kg}^{-1}$ dry weight). These findings suggest that the vines studied here may have received too much fertilizer (owing to the fact that microplots only represent $\approx 20 \%$ of the total vineyard surface area in the experimental vineyard) and that their high nutrient status invalidated the findings with respect to the water deficit applied. In other words, there is little reason to expect a drought treatment to alter nutrient partitioning to fruit clusters if the vines are being over-fertilized to begin with. This criticism can be ruled out, however, because the leaf nutrient status of the vines exposed to the differing irrigation treatments here was actually lower than the previous field study (Schreiner et al., 2006). This was particularly evident for $\mathrm{N}$ and for $\mathrm{P}$. Leaf blade $\mathrm{N}$ concentrations at harvest ranged from 10.9 to $12.3 \mathrm{~g} \cdot \mathrm{kg}^{-1}$ dry weight for the vines studied here as compared with 20 to $21 \mathrm{~g} \cdot \mathrm{kg}^{-1}$ dry weight in the previous field trial. Leaf blade $P$ at harvest ranged from 0.9 to $1.1 \mathrm{~g} \cdot \mathrm{kg}^{-1}$ dry weight for vines here, whereas they were 1.3 to $1.4 \mathrm{~g} \cdot \mathrm{kg}^{-1}$ dry weight previously. Leaf $\mathrm{K}$ was also higher previously than in the present study. Therefore, the vines used here to test if a late-season water deficit alters nutrient accumulation in fruit clusters actually had a lower nutrient status than the older field-grown vines examined before. In addition, the leaf blade nutrient concentrations of $\mathrm{N}, \mathrm{P}$, and $\mathrm{K}$ at the time of veraison in this study (data not shown) were $\approx 50 \%$ lower than corresponding $\mathrm{N}, \mathrm{P}$, and $\mathrm{K}$ concentrations in leaf blades at véraison from numerous other studies with 'Pinot noir' in the region (Schreiner, 2005, 2010; Schreiner et al., 2013). We suspected that young vine nutrient import to clusters would be more sensitive to drought stress than in older vines, because nutrient reserves stored in permanent vine structures (roots and trunks) are not yet developed in young vines. Evidently, even young vines transport nutrients efficiently to 
developing fruit clusters irrespective of water supply during ripening. However, the lack of $\mathrm{N}$ and $\mathrm{P}$ responses is not surprising, because the largest seasonal increase in whole-vine nutrient uptake of both $\mathrm{N}$ and $\mathrm{P}$ occurs before véraison (Schreiner et al., 2006).

The manner in which we stressed vines in this study is similar to vines that are typically managed with irrigation in arid climates (irrigation is applied after reaching defined stress level based on $\theta_{\mathrm{v}}$ or $\Psi_{\text {leaf }}$; Tarara et al., 2011), but this is indeed quite different from non-irrigated vineyards. Late-season water stress that develops more slowly but persistently over time may result in a different outcome. Our findings here may not apply to non-irrigated vineyards, but should apply to irrigated sites and would have broader applicability to younger vineyards. Although there are potential problems in extrapolating results from microplots to commercial vineyards (as a result of higher root density in microplots and lack of deep roots), our main finding that fairly severe drought stress after véraison does not alter yield or nutrients in fruit clusters would often apply to some dryland vineyards in western Oregon because we rarely observe drought stress (based on $\left.\Psi_{\text {leaf }}\right)$ that is as severe as what we attained here in microplots (Sweet and Schreiner, 2010; P.A. Skinkis and R. P. Schreiner, unpublished data). Further work is in progress to better define how water stress at different times and intensities affects 'Pinot noir' production, quality, and vine nutrient status.

\section{Literature Cited}

Bell, S. and P.A. Henschke. 2005. Implication of nitrogen nutrition for grapes, fermentation and wine. Austral. J. Grape Wine Res. 11:242-295.

Bely, M., J.M. Sablayrolles, and P. Barre. 1990. Automatic detection of assimilable nitrogen deficiencies during alcoholic fermentation in oenological conditions. J. Ferment. Bioeng. 70:246-252.

Cook, J.A., W.R. Ward, and A.S. Wicks. 1983. Phosphorus deficiency in California vineyards. Calif. Agr. 37:16-18.

Esteban, M.A., M.J. Villanueva, and J.R. Lissarrague. 1999. Effect of irrigation on changes in berry composition of Tempranillo during maturation. Sugars, organic acids, and mineral elements. Amer. J. Enol. Viticult. 50:418-434.

Etchebarne, F., H. Ojeda, and A. Deloire. 2009. Influence of water status on mineral composition of berries in 'Grenache Noir' (Vitis vinifera L.). Vitis 48:63-68.
Flexas, J., J. Bota, J.M. Escalona, B. Sampol, and H. Medrano. 2002. Effect of drought on photosynthesis in grapevines under field conditions: An evaluation of stomatal and mesophyll limitations. Funct. Plant Biol. 29:461-471.

Freeman, B.M. and W.M. Kliewer. 1983. Effect of irrigation, crop level and potassium fertilization on Carignane vines. II. Grape and wine quality. Amer. J. Enol. Viticult. 34:197-207.

Gibberd, M.R., R.R. Walker, D.H. Blackmore, and A.G. Condon. 2001. Transpiration efficiency and carbon-isotope discrimination of grapevines grown under well-watered conditions in either glasshouse or vineyard. Austral. J. Grape Wine Res. 17:110-117.

Hepner, Y. and B. Bravdo. 1985. Effect of crop level and drip irrigation scheduling on the potassium status of Cabernet Sauvignon and Carignane vines and its influence on must and wine composition and quality. Amer. J. Enol. Viticult. 36:140-147.

Jones, J.B. and V.W. Case. 1990. Sampling, handling, and analyzing plant tissue samples, $\mathrm{p}$. 389-427. In: Westerman, R.L. (ed.). Soil testing and plant analysis. 3rd Ed. Soil Science Society of America, Madison, WI.

Klein, I., M. Strime, L. Fanberstein, and Y. Mani. 2000. Irrigation and fertigation effects on phosphorus and potassium nutrition of winegrapes. Vitis 39:55-62.

Lee, J. and R.P. Schreiner. 2010. Free amino acid profiles from 'Pinot noir' grapes are influenced by vine $\mathrm{N}$-status and sample preparation method. Food Chem. 119:484-489.

Lovisolo, C., I. Perrone, W. Hartung, and A. Schubert. 2008. An abscisic acid-related reduced transpiration promotes gradual embolism repair when grapevines are rehydrated after drought. New Phytol. 180:642-651.

Matthews, M.A. and M.M. Anderson. 1988. Fruit ripening in Vitis vinifera L.: Responses to seasonal water deficits. Amer. J. Enol. Viticult. 39:313-320.

Medrano, H., J.M. Escalona, J. Bota, J. Gulías, and J. Flexas. 2002. Regulation of photosynthesis of $\mathrm{C}_{3}$ plants in response to progressive drought: Stomatal conductance as a reference parameter. Ann. Bot. (Lond.) 89:895-905.

Mpelasoka, B.S., D.P. Schachtman, M.T. Treeby, and M.R. Thomas. 2003. A review of potassium nutrition in grapevines with special emphasis on berry accumulation. Austral. J. Grape Wine Res. 9:154-168.

Naor, A., B. Bravdo, and Y. Hepner. 1993. Effect of post-véraison irrigation level on Sauvignon blanc yield, juice quality and water relations. S. Afr. J. Enol. Viticult. 14:19-25.

Nicolini, G., R. Larcher, and G. Versini. 2004. Status of yeast assimilable nitrogen in Italian grape musts and effects of variety, ripening and vintage. Vitis 43:89-96.
Reynolds, A.G. and A.P. Naylor. 1994. 'Pinot noir' and 'Riesling' grapevines respond to water stress duration and soil water-holding capacity. HortScience 29:1505-1510.

Schreiner, R.P. 2005. Spatial and temporal variation of roots, arbuscular mycorrhizal fungi, and plant and soil nutrients in a mature Pinot noir (Vitis vinifera L.) vineyard in Oregon, USA. Plant Soil 276:219-234.

Schreiner, R.P. 2010. Foliar sprays containing phosphorus $(\mathrm{P})$ have minimal impact on 'Pinot noir' growth and $\mathrm{P}$ status, mycorrhizal colonization, and fruit quality. HortScience 45:815821.

Schreiner, R.P., J. Lee, and P.A. Skinkis. 2013. N, $\mathrm{P}$, and $\mathrm{K}$ supply to Pinot noir grapevines: Impact on vine nutrient status, growth, physiology, and yield. Amer. J. Enol. Viticult. 64:26-38.

Schreiner, R.P., C.F. Scagel, and J. Baham. 2006. Nutrient uptake and distribution in a mature 'Pinot noir' vineyard. HortScience 41:336345.

Skinkis, P.A. and R.P. Schreiner. 2011. Grapevine nutrition. Oregon State University Extension Service, EM 9024.

Steyn, W.J., S.J.E. Wand, D.M. Holcroft, and G. Jacobs. 2002. Anthocyanins in vegetative tissues: A proposed unified function in photoprotection. New Phytol. 155:349-361.

Sweet, R.M., and R.P. Schreiner. 2010. Alleyway cover crops have little influence on Pinot noir grapevines (Vitis vinifera L.) in two western Oregon vineyards. Amer. J. Enol. Viticult. 61:240-252.

Tarara, J.M., J.E. Perez Peña, M. Keller, R.P. Schreiner, and R.P. Smithyman. 2011. Net carbon exchange in grapevine canopies responds rapidly to timing and extent of regulated deficit irrigation. Funct. Plant Biol. 38:386400.

Tomás, M., H. Medrano, A. Pou, J.M. Escalona, S. Martorell, M. Ribas-Carbó, and J. Flexas. 2012. Water-use efficiency in grapevine cultivars grown under controlled conditions: Effects of water stress at the leaf ands whole-plant level. Austral. J. Grape Wine Res. 18:164-172.

Wade, J., B. Holzapfel, K. Degaris, D. Williams, and M. Keller. 2004. Nitrogen and water management strategies for wine-grape quality. Acta Hort. 640:61-67.

Wright, J.L., R.G. Allen, and T.A. Howell. 2000. Conversion between evapotranspiration references and methods, p. 251-259. In: Evans, R.G., B.L. Benham, and T.P. Trooien (eds.). National Irrigation Symposium: Proc. of the 4th Decennial Symposium. American Society of Agricultural Engineers, St. Joseph, MI. 